\title{
Probing Consumer Awareness \& Barriers Towards Consumer Social Responsibility: A Novel Sustainable Development Approach
}

\author{
Mamta Soni ${ }^{*}$, Sunny Dawar ${ }^{1}$, Amit Soni $^{2}$ \\ ${ }^{1}$ Faculty of Management \& Commerce, Manipal University Jaipur, Jaipur 303007, Rajasthan, India \\ ${ }^{2}$ Department of Electrical Engineering, Manipal University Jaipur, Jaipur 303007, Rajasthan, India
}

Corresponding Author Email: mamtasoni_09@yahoo.co.in

https://doi.org/10.18280/ijsdp.160109

Received: 23 July 2020

Accepted: 18 November 2020

\section{Keywords:}

consumer's awareness, consumer social responsibility (CNSR), corporate social responsibility (CSR), sustainable development, green consumption barriers, push \& pull development

\begin{abstract}
Global scenario has revealed paucity of consumers' awareness towards their socia responsibilities which is certainly crucial to step forward on path of sustainable development. Regulating corporates practices has practically struggled for resource wastage reduction, dipping environmental harm, and improving societal welfare. Only corporates efforts are insufficient for desired improvement of societal \& environmental health and demand consumers understanding their responsible actions towards society \& environment. Centre of attention is to identify relationship between Consumer Social Responsibility (CnSR) and Corporate Social Responsibility (CSR). This relationship is endeavored by means of relationship matrix in which four unique developments are considered and accordingly solutions are suggested. Existence of barriers hindering consumers green decisions have been observed and addressed for better understanding. A total of 600 structured questionnaires were distributed, of which 457 returned and included incomplete contents also. Analysis is finally executed using 429 complete responses. Results are utilized to overcome barriers and improvise the consumers' awareness towards various antecedents of $\mathrm{CnSR}$ for required sustainable consumption. Consumers' requires support towards sustainable choices and as their awareness level will increase, they will start understanding the implications of their consumption choices leading to long-term sustainable practices.
\end{abstract}

\section{INTRODUCTION}

Present scenario worldwide reflects major role of technological advancements for augmenting comfort in human life. Further, this growth experienced are associated with numerous environmental challenges which comprises global warming, energy \& water scarcity issues, pollution etc. Required environment equilibrium will be achieved when patterns for consumption and production endorses "minimal or zero harm" which will lead towards Sustainable Development. Sustainability is optimum or minimal utilization of available resources for present need and preserving these for next generation. Reflections made in United Nations report [1]; clearly indicates water as utmost important component for the survival of life on Earth. Analyzing facts revealed that presently, water is not reachable to more than one billion people and if this situation remains then most people will be affected by severe shortage of fresh water by 2050 . Similarly, food wastage figures recorded due to inferior transit and harvest methods are also shocking. This indicates that most of the food material gets wasted by rotting in consumers and retailers' bins. To add furthermore, air pollution is another serious concern which indicates that almost nine out of ten people inhale polluted air across the world. Results recorded indicates that every year, about seven million people experience death due to air pollution. Facts recorded are alarming and seriously raise demand for rigorous steps towards Sustainable consumption and production practices.
From last many decades, world economies have been interminably struggling for required sustainable development. In view of the same, production and consumption are required to be mapped accordingly with an aim to make Earth, a better place for survival of all. As far as production is concerned, many efforts are already being attempted with the support of legal framework. One of such popular frameworks is Corporate Social Responsibility (CSR), where corporates' are stressing much more on environmental performance over the economic one considering pressures from governments, NGO's and customers [2]. Researchers have shown that corporate houses have been trying hard to fulfill their part of social responsibility through CSR activities [3]. But facts recorded indicates that, CSR activities can only contribute for some portion of corporates' profit towards societal developments. Alternatively, this is observed that if we consider sustainable production then this can only be achieved through consumers' actions. Today's scenario clearly reflects that in pressure of CSR rules, the corporates' are pursuing CSR activities which further lead to little welfare of society. Further, this is elaborated that steps such as: eco-friendly innovations, optimum resource utilization and corporate social activities [4]; helps in drawing picture of Industrial sustainability but are insufficient in delivering long term sustainability. Sustainability dream cannot be only fulfilled through framed CSR activities [5]; and in view to achieve this, consumers are required to be put into frame. CSR activities have also attributed positive effects on consumers, as they get attracted 
towards corporates' and shows their positive response through buying these companies products [6]. In addition, companies' environmental commitments as well as product quality both are important for the consumer decision making [7]. Consumers do value for their social responsibility but not all dimensions are equally important for them [8]. One of the most practical fact is this that, consumer's actual behavior does not always resemble along with their purchase intentions [9]. Price and quality of a product $[10,11]$ always rules when actual buying takes place and lack of consumers' awareness is responsible reason for consumers non-green behavior. Lack of awareness of consumers can be broadly mapped through proper utilization of social media platform, where most of population is spending their major time span [12]. The substantial role of governments and other organizations [13]; is also reflected for transmitting sustainability related information to the consumers. Further, conspicuous consumption [14]; also plays vital role to encourage wastage of resources which people pursue for showing their economic power and for fulfilling their status needs. There exist substantial role of energy, water, and environment as three most prominent strategic issues towards sustainable development [15]. In general, consumers generally do not consider adoption of green products [16]; on urgent basis, but at later stages agree to adopt the same. Detailed review presented above provides clear perception that, for the sake of good health of environment and society at large, it is correct time to develop awareness among consumers' regarding their social responsibility. This will direct them to behave in a responsible manner while framing their purchase decisions. Desired consumers' awareness and understanding about their social responsibility towards purchase decisions will initiate corporates' to move further in more responsible manner on the path of sustainable production. In this paper, for the first-time unique approach which will firmly define Consumer Social Responsibility (CnSR) is presented with an aim to develop consumers understanding towards their social responsibility and to encourage sustainable production. In today's scenario there is crucial need that every individual and institution should understand power of their actions and act accordingly. In addition, this is also required that consumers' and corporates' jointly step towards betterment of the environment and societal welfare.

\section{MATERIALS AND METHODS}

\subsection{Consumer social responsibility $(\mathrm{CnSR})$}

Consumer social responsibility (CnSR) is an understanding which elaborates social responsibility of consumers that has been mentioned in past researches through various proposed terminologies such as: responsible consumption [17]; socially conscious consumer [18]; socially responsible consumers [19, 20] and Consumer social responsibility (CnSR) [21]. Further, researchers clearly mentioned that, CSR activities cannot be successfully planned in isolation and they are required to be supported through consumers' actions [22]. Support system provided by consumers' actions through self-adoption of green practices for entire societal \& environmental welfare is defined as Consumer social responsibility (CnSR). Further, sole reason of corporate investment in CSR activities is to develop positive public relations, as consumers also pursue their self-interest by seeking price efficient products. This practice will continue until consumers start realizing their responsibility and support for the promotion of green products. Similar to corporate CSR roles, consumers should also be held responsible for using their 'purchase votes' to effect positive social outcomes [23]. Further, more explicitly this can be elaborated that consumers hold high buying power over entire producers of products $\&$ services and hence it is quite unfair to rest all burden of social responsibility on the shoulders of corporate houses alone [24]. Specifically, for fruitful results of CSR activities this is required to be linked with $\mathrm{CnSR}$, then only the desired sustainable development can be attained [25]. Same is explained over here by means of systematic representation linked with CSR and CnSR activities plotted in Figure 1.

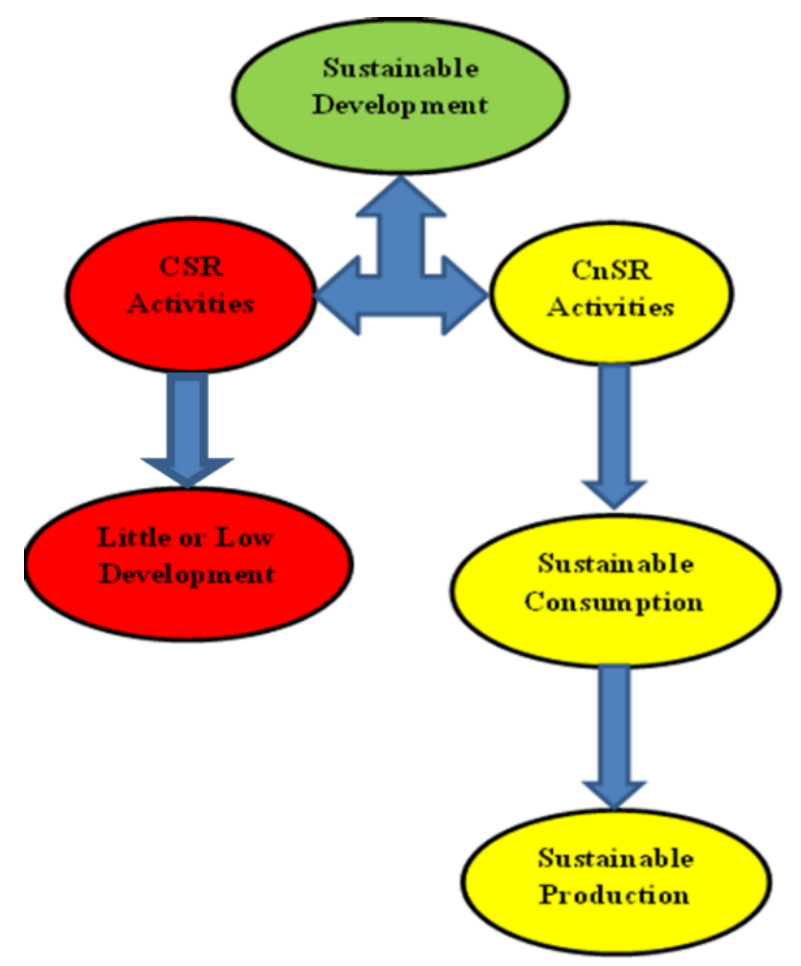

Figure 1. CSR and CnSR activities in seclusion and arrangement

Consumers' understanding towards their responsibility will encourage them for green choices, that will further help in generating demand for green products. This increased demand will help in large scale production and will ultimately lead to economies of scale that will be surely benefitting the consumers' and corporates, resulting increase of the green products which will reduce per unit cost and finally pull sustainable production in the economy. Relatively this enhanced green products demand will also be encouraging corporates to produce the same.

To achieve sustainable vision, corporate's, and consumers both are required to actively contribute, otherwise this cannot be materialized. In addition, practically green production is involved with huge investment and can be pursued profitably with the help of consumers demand. To summarize the same, we can conclude that for sustainability to happen, it is necessary that the corporates' and consumers' act in parallel towards green environment and societal welfare. An understanding must be developed in the economy between consumers' and corporates' and an awareness should be generated about how their joint efforts can be prove bliss for sustainable development. The joint effort of both consumers 
and corporates in the unidirectional manner will lead towards the path of sustainable development.

Consumer Awareness: Probing awareness of the consumers about Consumer Social Responsibility (CnSR) was the first step, and to access the same a unique questionnaire was framed considering all desired parameters. The questionnaire constituted was having four main antecedents of CnSR which are termed as: (i) Environmental Orientation (EO) (ii) Ethical \& Moral Disposition (EMD) (iii) Spiritual Orientation (SO) and (iv) Orientation towards Shared Consumption (OSC). All the identified four antecedents include various parameters such as animal testing, child labor, 3R's (Recycle, Reuse and Reduce), employee working conditions, foreign and counterfeit products, etc. for the desired purpose of evaluation.

Assurance towards accuracy level of the framed questionnaire was achieved through proper analysis done through subject professionals. Further, reliability testing of the tool i.e. Cronbach's Alpha was also calculated which has revealed the value as 0.953 and hence confirms anticipated precision. Final questionnaire after duly implementing all suggested alterations was then circulated among respondents using online and offline mode. In total, we have got 429 respondents' data collected which was evaluated for analyzing desired awareness. We have collated in Table 1, the number and percentage of respondents for all raised questions against the Likert Scale. In addition, computed mean scores and overall status is presented in Table 2 and Figure 2 for clarity.

For sampling which plays important role to enrich accuracy of computations performed, target population is segregated in terms of consumer population and their purchasing capability which has diverse impact on society and environment at large. In addition, demographics which includes factors such as age, income, gender, education, marital status, occupation etc. are also implemented. Data analyzed includes unique identities of consumers' and most of respondents are graduates and post-graduates. Another interesting fact is that respondents are mostly males $(60 \%)$ having younger age $(50 \%)$ which are self-dependent people (45\%) and occupies substantially good annual earnings (70\%). For clear picture of data corresponding values and results obtained are presented here in Table 3. This will be helpful to draw a clear picture of target population which may not be grasped in elaboration done above.

\subsection{CnSR barriers}

Sustainability path is also associated with several hurdles or barriers which will hinder desired purpose. Past researchers have also pointed related to such blockades for the same. This was stated [26] that 'Willingness to pay' as potent barrier for green consumption and mentioned that consumers found green products to be more expensive one in comparison to the nongreen goods. In addition, 'price' as the strong barrier [27] that restricts consumers towards going green. Other than price, important factors such as quality, perception, convenience in acquiring green products and brand loyalty which has played significant role in affecting consumers' green preferences [28]. This has been mentioned, about distrust feeling among consumers raised towards green claims made by companies where they feel that green promises are only the promotional part and selling tricks of these companies. Some researchers have also complained about non-availability of green goods in the nearby stores which have left consumers with use of available conventional products. The lack of consumers' education is an important barrier towards green offerings [29]. This has specifically pointed consumers' decision making as largely influenced through their family and friends' choices which certainly interfere in making green choices [30]. For the successful attainment of sustainable development, it is vital to overcome above discussed barriers. To attain this, corporates, governments, and NGOs must analyze for the hindrances in consumers' green choices and need to take necessary actions to overcome the situation of non-green practices.

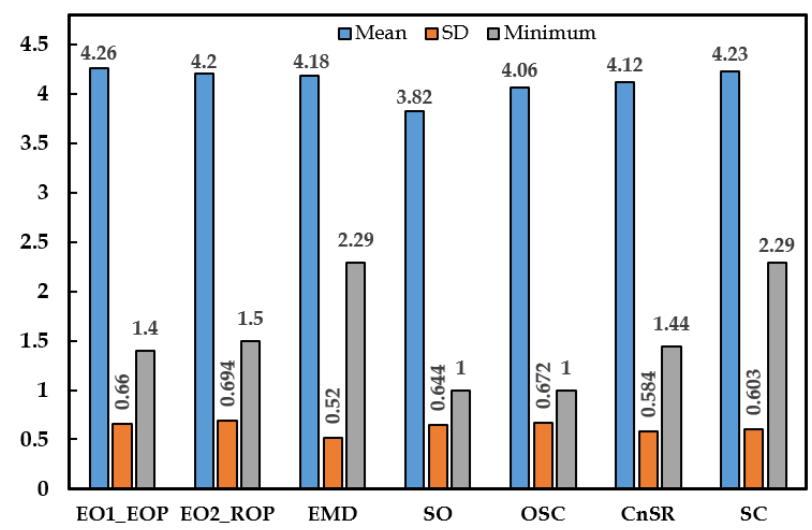

Figure 2. Bar representation of mean-median analysis of CnSR antecedents

Table 1. Recorded responses against various antecedents of $\mathrm{CnSR}$

\begin{tabular}{|c|c|c|c|c|c|}
\hline Particulars & $\begin{array}{l}\text { Strongly } \\
\text { Disagree }\end{array}$ & Disagree & Neutral & Agree & Strongly Agree \\
\hline \multicolumn{6}{|c|}{ A. ENVIRONMENTAL ORIENTATION (EO1_EOP \& EO2_ROP) } \\
\hline Do not buy products which are harmful to environment. & (9) 2.1 & (21) 4.9 & $(33) 7.7$ & (159) 37.1 & (207) 48.3 \\
\hline Do not buy product made up from animal substances. & (18) 4.2 & (33) 7.7 & (54) 12.6 & (126) 29.4 & (198) 46.2 \\
\hline Like to consume recycle products. & 0 & (12) 2.8 & (54) 12.6 & (198) 46.2 & (165) 38.5 \\
\hline Use those products that can be reused after consumption. & (6) 1.4 & (3) 0.7 & (57) 13.3 & (195) 45.5 & (168) 39.2 \\
\hline $\begin{array}{c}\text { Prefer cloth or jute or paper bags for shopping instead of } \\
\text { plastic ones. }\end{array}$ & (6) 1.4 & 0 & (27) 6.3 & (99) 23.1 & (297) 69.2 \\
\hline $\begin{array}{l}\text { Do not to use the goods that increase the environmental } \\
\text { contamination. }\end{array}$ & (6) 1.4 & (15) 3.5 & (33) 7.7 & (165) 38.5 & (210) 49 \\
\hline Prefer organic products over inorganic products. & (6) 1.4 & (9) 2.1 & (90) 21 & (150) 35 & (174) 40.6 \\
\hline \multicolumn{6}{|c|}{ B. ETHICAL \& MORAL DISPOSITION (EMD) } \\
\hline $\begin{array}{l}\text { Employee satisfaction in the organization matters me to take } \\
\text { a purchase decision. }\end{array}$ & (3) 0.7 & (39) 9.1 & (96) 22.4 & (213) 49.7 & (78) 18.2 \\
\hline $\begin{array}{l}\text { Prefer companies which consider customers feedback } \\
\text { sincerely. }\end{array}$ & (6) 1.4 & (3) 0.7 & (39) 9.1 & (186) 43.4 & (195) 45.5 \\
\hline
\end{tabular}


Do not use products which have been produced using child labour.

Do not consume those products which cause health issues (e.g. tobacco).

Consume products having less preservatives, additives, and artificial colouring.

Give preference to domestic products over foreign products. Avoid consuming counterfeit products.

\begin{tabular}{lcccc} 
(6) 1.4 & (15) 3.5 & (63) 14.7 & (117) 27.3 & (228) 53.1 \\
(6) 1.4 & (6) 1.4 & (21) 4.9 & (96) 22.4 & (300) 69.9 \\
(9) 2.1 & (9) 2.1 & (39) 9.1 & $(195) 45.5$ & (177) 41.3 \\
(6) 1.4 & (21) 4.9 & (90) 21 & (156) 36.4 & (156) 36.4 \\
(9) 2.1 & (3) 0.7 & (60) 13.9 & (204) 47.6 & (153) 35.7 \\
\hline ORIENTATION (SO) & & & \\
(9) 2.1 & (18) 4.2 & (72) 16.8 & (207) 48.3 & (123) 28.7 \\
(6) 1.4 & (12) 2.8 & (108) 25.2 & (186) 43.4 & (117) 27.3 \\
(12) 2.8 & (15) 3.5 & (93) 21.7 & (207) 48.3 & (102) 23.8 \\
(3) 0.7 & (18) 4.2 & (96) 22.4 & (216) 50.3 & (96) 22.4 \\
(33) 7.7 & (78) 18.2 & (78) 18.2 & (165) 38.5 & (75) 17.5
\end{tabular}

\section{SPIRITUAL ORIENTATION (SO)}

Focus more on fulfilment of basic needs rather than luxuries.

Consume products of those companies which donate for social welfare.

Buy those products whose sales supports social cause.

Like to buy brands of those companies which support community.

$\begin{array}{lcc}(33) 7.7 & (78) 18.2 & (78) 18.2\end{array}$

Provide products to others which I am not using.

(9) 2.1

(18) 4.2

(51) 11.9

(222) 51.7

(129) 30.1 resources.

(3) 0.7

(6) 1.4

(45) 10.5

(240) 55.9

(135) 31.5

Work to create awareness about product sharing to reduce depletion of resources.

(9) 2.1

(18) 4.2

(75) 17.5

(195) 45.5

(132) 30.8

(3) 0.7

(12) 2.8

(48) $11.2 \quad$ (252) 58.7

(114) 26.6

I think product sharing also avoids over-storage of products.

\section{E. CONSUMER}

\section{corporate houses.}

I have a responsibility to maintain environmental health.

Consider my responsibility to make a difference on

environmental issues like waste management, electricity consumption etc.

I always give feedback to concerned authorities about their responsibilities towards society.

Consider my responsibility to improve the weaker section of the society.

I consider environmental issues in day to day consumption practices.

I focus on ethical and moral practices exercised by companies.

I support weaker section of the society by doing charities and donations from time to time.

Prefer those companies' brands which fulfil legal responsibilities.
(9) 2.1

(3) 0.7

(48) 11.2

(231) 53.8

(138) 32.2

(6) 1.4

(3) 0.7

(21) 4.9

(156) 36.4

(243) 56.6

(3) 0.7

0

(30) 7

(189) 44.1

(207) 48.3

$\begin{array}{lllll}0 & \text { (21) } 4.9 & \text { (117) } 27.3 & \text { (183) } 42.7 & \text { (108) } 25.2\end{array}$

$\begin{array}{lllll}(3) & 0.7 & \text { (6) } 1.4 & \text { (66) } 15.4 & \text { (228) } 53.1\end{array}$

$\begin{array}{llll}(3) & 0.7 & \text { (6) } 1.4 & \text { (45) } 10.5\end{array}$

(135) 31.5

(3) 0.7

(12) 2.8

(90) 21

(216) 50.3

(108) 25.2

(2) 1.4

(12) 2.8

(105) 24.5

(192) 44.8

(114) 26.6

(3) 0.7

(6) 1.4

(75) 17.5

(216) 50.3

(129) 30.1

\section{F. SUSTAINABLE CONSUMPTION (SC)}

I believe in green consumption practices motivating sustainable production.

I believe to consider sustainable/green products instead of selecting usual products.

I believe that my consumption activities (i.e. purchase and use) have an impact on the environment.

Individuals should be careful when purchasing products,

because consumption of certain products possibly have more harmful impacts on the environment.

Prefer to consume products whose packaging is eco-friendly.

Green product usage saves environment and society

Consume products that can be recycled /reused.
(6) 1.4

0

(45) 10.5

(222) 51.7

(156) 36.4

(3) 0.7

(6) 1.4

(75) 17.5

(216) 50.3

(129) 30.1

(3) 0.7

(9) 2.1

(48) 11.2

(207) 48.3

(162) 37.8

(6) 1.4

(6) 1.4

(42) 9.8

(195) 45.5

(180) 42
(3) 0.7
(9) 2.1
0

(6) 1.4

(48) 11.2

(6) 1.4

(33) 7.7

(210) 49

(150) 35

(162) 37.8

(9) 2.1

(51) $11.9 \quad$ (174) 40.6

Table 2. Mean-Median analysis of different antecedents of CnSR

\begin{tabular}{ccccc}
\hline Factor & Mean & SD & Minimum & Maximum \\
\hline EO1_EOP & 4.26 & 0.66 & 1.00 & 5.00 \\
EO2_ROP & 4.20 & 0.69 & 1.00 & 5.00 \\
EMD & 4.18 & 0.52 & 1.00 & 5.00 \\
SO & 3.82 & 0.64 & 1.00 & 5.00 \\
OSC & 4.06 & 0.67 & 1.00 & 5.00 \\
CnSR & 4.12 & 0.58 & 1.00 & 5.00 \\
SC & 4.23 & 0.60 & 1.00 & 5.00 \\
\hline
\end{tabular}


Table 3. Demographic characteristics of responses

\begin{tabular}{|c|c|c|c|}
\hline & Measure & Responses & Percentage \\
\hline \multirow{4}{*}{ Age } & $<20$ years & 126 & 29.37 \\
\hline & 20-30 years & 111 & 25.87 \\
\hline & $30-40$ years & 129 & 30.07 \\
\hline & $>40$ years & 63 & 14.69 \\
\hline \multirow{2}{*}{ Gender } & Male & 255 & 59.44 \\
\hline & Female & 174 & 40.56 \\
\hline \multirow{3}{*}{ Income } & $<5 \mathrm{LPA}$ & 114 & 26.57 \\
\hline & 5-10 LPA & 150 & 34.97 \\
\hline & $>10 \mathrm{LPA}$ & 165 & 38.46 \\
\hline \multirow{4}{*}{ Occupation } & Home Maker & 42 & 9.79 \\
\hline & Student & 195 & 45.45 \\
\hline & Service & 168 & 39.16 \\
\hline & Business & 24 & 5.59 \\
\hline \multirow{3}{*}{ Education } & Under-Graduate & 174 & 40.56 \\
\hline & Post-Graduate & 159 & 37.06 \\
\hline & Higher than Post-Graduate & 96 & 22.38 \\
\hline \multirow{2}{*}{ Marital status } & Married & 219 & 51.05 \\
\hline & Unmarried & 210 & 48.95 \\
\hline
\end{tabular}

\subsection{Reducing barriers}

To attain for sustainability, we will have to plan for techniques of barrier reduction. To attempt this, first and utmost important step is to create consumers awareness, and this can be achieved through different means such as: Family \& Friends, Product Label, Magazines \& Journals and through Social Networking.

Practical analysis requires collection of inclined feedbacks from various stakeholders and the same is expressed here in Figure 3 where we have presented the variable sources along with percentage of feedbacks received. Results collated reflects that awareness of consumers is majorly governed through social networking and family \& friends (35.7 \%).

Further, the other two means i.e. product labels and magazine \& journals contributes up to $13-15 \%$ only which indicates their lower direct influence. In this manner, proper division related to different sources of information can be clearly mentioned which will help to provide required clarity and understanding. This will help to increase consumer awareness and hence finally reduce the barriers. For better response, feedback from all the stakeholders is collated rigorously after creating desired awareness through various means.

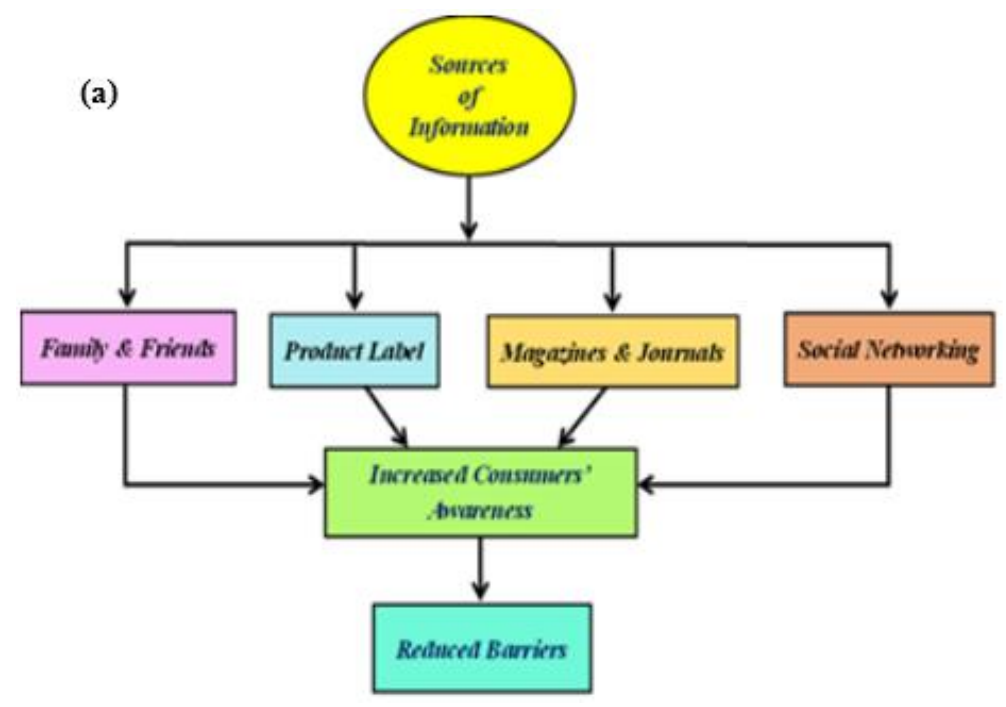

(b)

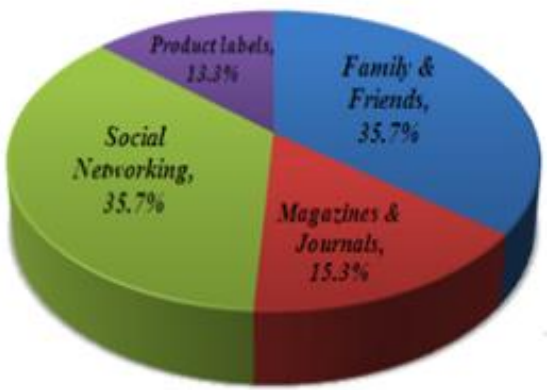

Figure 3. (a) Sources of information for reducing barriers. (b) Percentage contribution of different awareness means

\subsection{CSR and CnSR relationship matrix}

Relationship projected will be completely depends upon the way optimum utilization of resources for production can be pursued along with minimum wastage. But all these efforts will be failure until consumers starts understanding their required role towards social responsibility and will start performing in the same direction. In view of the same, we have developed a unique 2 × 2 matrix and represented this over here in Figure 4.

\begin{tabular}{|c|c|c|c|}
\hline \multirow{2}{*}{ High } & $\begin{array}{c}\text { Sustainable } \\
\text { Developm ent }\end{array}$ & $\begin{array}{c}\text { Push } \\
\text { Development }\end{array}$ \\
\cline { 2 - 4 } & Low & $\begin{array}{c}\text { Pull } \\
\text { Developm ent }\end{array}$ & $\begin{array}{c}\text { No or Low } \\
\text { Development }\end{array}$ \\
\cline { 2 - 4 } & & High & Low \\
\hline \multicolumn{3}{|c|}{ CnSR Activities } \\
\hline
\end{tabular}

Figure 4. CSR and CnSR relationship matrix 
In this matrix, $\mathrm{CnSR}$ activities are represented on abscissa and CSR activities on ordinate indicating their two levels of activities along with four different types of developments mentioned here in marked levels. For better understanding, we have elaborated these developments in detailed fashion over here and have attempted to study their inter-relationships. The same is discussed along with desired justifications as:

\section{(1) Sustainable Development}

The process related to betterment of life for all sectors such as: economic, social, educational, health care, food and energy independence, national security etc. is termed as Sustainable Development. As depicted from the above Figure 2, an economy with higher CSR and CnSR activities indicates sustainable development. In this type of economy, corporates' as well as consumers' treat themselves socially responsible, hence together make efforts for societal welfare and environmental green health. Further, here consumers are well aware about their purchasing power effects, hence utilize this with clear inclination towards green production practices and green products. In such economies, sustainable lifestyles will be observed which will result in sustainable development setting an example case for the rest.

\section{(2) Push Development}

Next important one is push development, where corporates are fulfilling desired role towards societal and environmental welfare, but consumers' actions are very less in this direction. Consumers are of opinion that primarily corporates are responsible to work for societal welfare, as they are making huge amount of profits from society. Development towards societal upliftment is sought through corporates' CSR activities, Government actions, NGO's efforts and for consumers' awareness towards social responsibility it should be created via media. There can be some barriers also which might be stopping consumers' for going green, so these barriers should be identified and required to be acted aptly for overcoming the same.

\section{(3) Pull Development}

Consumers' understanding of responsibility and actions are high over here when compared with corporates. Here, green purchasing behaviour of consumers' pull the corporates' towards green production and hence brings the development in the economy. Further, to improvise the corporates' responsibility they can be put into legal framework by governing authorities.

\section{(4) No or Low Development}

In this type of set up, consumers and corporates both are on low level in fulfilling their social responsibility. This is due to several reasons such as: lack of awareness, poor legal framework, barriers that consumers and corporates face in going green, low income economies, lack of resources and infrastructure facilities, etc. Here, governments and NGO's role will be on top for the upliftment of society and other supreme economies can also come forward.

\section{RESULTS AND DISCUSSION}

Sustainability is the need of the hour and must be achieved through various efforts of corporates' as well as consumers. Researchers have emphasized on active involvement of CSR activities for the societal and environmental welfare. But practically, there exist various barriers on consumers' part, which hinders process of sustainability and should be attempted to achieve long term benefits. Different sources of information's (Figure 2) will help for gaining knowledge related to green products and practices. As described, major sources are social networking, family \& friends, product labeling and magazines. Resulted survey revealed major impact (35\%) from social networking and family \& friends for information gathering. Similarly, minor contribution (13$15 \%)$ is observed through product labels and magazines \& journals. Further, to reduce lack of awareness this is suggested to educate consumers' regarding desired patterns of consumption linked directly with the environmental health. Consumers' awareness about the ill effects of their consumption on environment and society will help in adoption of consumption choices in the favor of environment and society.

As suggested by several respondents, CnSR activities are suggested to be included in some legal framework as considered for CSR activities. Although, this is certainly not an easy task, but can be attempted through proper communication programs to alter their consumption patterns. In addition, price is also required to be handled, as this has been observed that consumer decisions are price sensitive. Awareness should be spread about how shift of consumers' demand towards green products will enable the producers to decrease the 'per unit' cost and ultimately benefitting both consumers and producers. Responses received are mentioned from Table 1 and are segregated in terms of individual perspectives over here in Table 2. Same is more clearly reflected in Figure 2 which highlights the mean-median analysis of CnSR identified antecedents.

Analyzing submitted responses concludes with several observations which will be helpful to achieve sustainability. Firstly, distrust of consumers towards companies' green promises should be recovered by not indulging into any publicity stunts and through disseminating true information about the product features. Along with this corporates' must be having their strong distribution channel, so that the green products and services are available in the right time, place and to the right person. Furthermore, another biggest barrier is brand loyalty which can be proved to be difficult to handle as it is not very easy to shift brand loyal to another brand. To handle this barrier producers are required to understand the quality and satisfaction which consumers are getting from their brands and must generate an assurance of the consumers regarding equivalent or better-quality delivery. To involve consumers' in parallel with the corporates for the benefit of the society and environment at large, it is of utmost important to overcome the above-mentioned barriers. These steps will be helpful to achieve long term sustainability and will start a new era which will be good admixture of responsibility sharing by consumers and corporate's.

\section{CONCLUSIONS}

In this work, we have first time presented Consumer Social Responsibility (CnSR) awareness \& barriers towards novel sustainable development approach. This is realized that, consumers' are not much aware regarding green products availability and effect of their consumption pattern on the 
environment and society. Journey of CnSR begins with consumers' awareness towards green products along with its benefits for the environment and society. Proper awareness towards availability of green products, their advantages, ethical and moral parameters of the products utilized by consumers will surely alter consumption patterns. Consumers' requires support towards sustainable choices and as their awareness level will go high, they will start understanding the implications of their consumption choices leading to longterm sustainable practices.

Globalization and technological advancements have changed level of awareness and currently consumers' have become more cognizant towards various social and environmental issues. Awareness can be brought through different means that includes social media networking, proper advertising, product labeling, educational programs etc. through which dream of sustainable development can be achieved. In addition, price and quality of products and services dictates consumers' actual purchase decisions. Present work validates here development of unique CnSR \& CSR relationship matrix which is elaborated as useful tool for analyzing development type and formulates the strategies and policies according to the requirement. Further, it enables the practitioner in knowing where they are lacking at users or corporates end and helps to form policies towards the same to bridge the gap. For users, infotainment activities and programs can be pursued to tackle the situation. On the other hand, legal framework can be worked out to put a control over corporates' unsustainable practices and hence fixing the weaknesses in time. Present work has developed novel perspective and will be useful to create desired awareness among consumers towards CnSR to achieve long term environmental and societal sustainability.

\section{ACKNOWLEDGMENT}

Authors are thankful to Manipal University Jaipur for providing all necessary academic and financial support related to this work.

\section{REFERENCES}

[1] Guterres, A. (2019). The sustainable development goals report. United Nations, New York (NY), US. https://unstats.un.org/sdgs/report/2019.

[2] Dong, X., Li, H., Liu, S., Cai, C., Fan, X. (2018). How does material possession love influence sustainable consumption behavior towards the durable products? Journal of Cleaner Production, 198: 389-400 https://doi.org/10.1016/j.jclepro.2018.07.054

[3] Soni, M., Dawar, S. (2018). Exploring consumer social responsibility (CnSR): A key element for sustainable environment. International Conference on Advances in Science and Engineering Technology (ASET), Dubai, pp. 1-5. https://doi.org/10.1109/ICASET.2018.8376753.

[4] Bocken, N.M., Short, S.W., Rana, P., Evans, S. (2014). A literature and practice review to develop sustainable business model archetypes. Journal of Cleaner Production, 65: 42-56.

https://doi.org/10.1016/j.jclepro.2013.11.039

[5] Vitell, S.J. (2014). A case for consumer social responsibility (CnSR): Including a selected review of consumer ethics/social responsibility research. Journal of Business $\quad$ Ethics, 130(4): 767-774. https://doi.org/10.1007/s10551-014-2110-2

[6] Chang, H.H. (2017). Consumer socially sustainable consumption: the perspective toward corporate social responsibility, perceived value, and brand loyalty. Journal of Economics and Management, 13(2): 167-191.

[7] Feldman, P.M., Parraga, A.Z.V. (2013). Consumer social responses to CSR initiatives versus corporate abilities. Journal of Consumer Marketing, 30(2): 100-111. https://doi.org/10.1108/07363761311304915

[8] Arli, D.I., Tjiptono, F. (2018). Consumer ethics, religiosity, and consumer social responsibility: Are they related? Social Responsibility Journal, 14(2): 302-320. https://doi.org/10.1108/SRJ-03-2016-0036

[9] Groening, C., Sarkis J., Zhu, Q. (2018). Green marketing consumer-level theory review: A compendium of applied theories and further research directions. Journal of Cleaner Production, 172: 1848-1866. https://doi.org/10.1016/j.jclepro.2017.12.002

[10] Soni M., Dawar, S. (2018). Green consumption to consumer social responsibility (CNSR): A roadmap towards sustainable development. International Conference and Utility Exhibition on Green Energy for Sustainable Development (ICUE), Phuket, Thailand, pp. 1-6. $\quad$ https://doi.org/10.23919/ICUEGESD.2018.8635760

[11] Soni, M., Dawar, S. (2018). Exploring consumer social responsibility (CnSR): A key element for sustainable environment. International Conference on Advances in Science \& Engineering Technology (ASET), Dubai, pp. 1-5. https://ieeexplore.ieee.org/document/8376753

[12] Kampf, C.E. (2018). Connecting corporate and consumer social responsibility through social media activism. SI: Social Media, Activism and Organizations, 4(1): 1-11. https://doi.org/10.1177/2056305117746357

[13] Shao, J., Taisch, M., Mier, M.O. (2017). Influencing factors to facilitate sustainable consumption: From the experts' viewpoints. Journal of Cleaner Production, 142: 203-216. https://doi.org/10.1016/j.jclepro.2015.12.111

[14] Lo, L.W. (2018). Conspicuous green purchase intention: The mediating role of consumer ethics and conspicuous consumption. Global Marketing Conference, Tokyo, pp. 336-338.

[15] Urbaniec, K., Mikulčić, H., Rosen, M.A., Duić, N. (2017). A holistic approach to sustainable development of energy, water and environment systems. Journal of Cleaner Production, $155(1)$ : 1-11. https://doi.org/10.1016/j.jclepro.2017.01.119

[16] Tan, L.P., Johnstone, M., Yang, L.L. (2016). Barriers to green consumption behaviours: The roles of consumers' green perceptions. Australasian Marketing Journal (AMJ), 24(4): 288-299. https://doi.org/10.1016/j.ausmj.2016.08.001

[17] Fisk, G. (1973). Criteria for a theory of responsible consumption. Journal of Marketing, 37(2): 24-31.

[18] Jr, F.E.W. (1975). Determining the characteristics of the socially conscious consumer. Journal of Consumer Research, 2(3): 188-196. https://www.jstor.org/stable/2489054

[19] Antil, J.H. (1984). Socially responsible consumers: Profile and implications for public policy. Journal of Macro Marketing, 4(2): 18-39. https://doi.org/10.1177\%2F027614678400400203 
[20] Roberts, J.A. (1993). Sex differences in socially responsible consumers' behavior. Psychological Reports, 73(1): $139-148$ https://doi.org/10.2466\%2Fpr0.1993.73.1.139.

[21] Devinney, T.M., Auger, P., Eckhardt, G., Birtchnell, T. (2006). The other CSR: Consumer social responsibility. Stanford Social Innovation Review, 1-12. https://dx.doi.org/10.2139/ssrn.901863

[22] Vitell, S.J. (2015). A case for consumer social responsibility (CnSR): Including a selected review of consumer ethics/social responsibility research. Journal of Business $\quad$ Ethics, 130(4): 767-774. https://doi.org/10.1007/s10551-014-2110-2

[23] Caruana, R., Crane, A. (2008). Constructing consumer responsibility: Exploring the role of corporate communications. Organization Studies, 29(12): 14951519. https://doi.org/10.1177\%2F0170840607096387

[24] Ellen, P.S., Webb, D.J., Mohr, L.A. (2006). Building corporate associations: Consumer attributions for corporate socially responsible programs. Journal of the Academy of Marketing Science, 34(2): 147-157. https://doi.org/10.1177/0092070305284976

[25] Quazi, A., Amran, A., Nejati, M. (2016). Conceptualizing and measuring consumer social responsibility: A neglected aspect of consumer research. International Journal of Consumer Studies, 40(1): 48-56. https://doi.org/10.1111/ijcs.12211

[26] Moser, A.K. (2015). Thinking green, buying green? Drivers of pro-environmental purchasing behavior. Journal of Consumer Marketing, 32(3): 167-175. https://doi.org/10.1108/JCM-10-2014-1179

[27] Chirculescu, R.E., Preda, M.C. (2016). Barriers noticed in the consumption of ecological food products. Quality - Access to Success, 17(S1): 359-363.

[28] Gleim, M., Lawson, S.J. (2014). Spanning the gap: An examination of the factors leading to the green gap. Journal of Consumer Marketing, 31(6/7): 503-514. https://doi.org/10.1108/JCM-05-2014-0988

[29] Gabler, C.B., Butler, T.D., Adams, F.G. (2013). The environmental belief-behaviour gap: Exploring barriers to green consumerism. Journal of Customer Behavior, 12(2-3): $159-176$ https://doi.org/10.1362/147539213X13832198548292

[30] Gleim, M.R., Smith, J.S., Andrews, D., Cronin Jr, J.J. (2013). Against the green: A multi-method examination of the barriers to green consumption. Journal of Retailing, 89(1): https://doi.org/10.1016/j.jretai.2012.10.001 